ISSN 1991- 8690

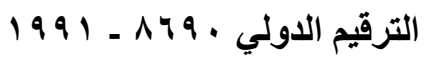

Website: http://jsci.utq.edu.iq

Email: utjsci@utq.edu.iq

\title{
In Vitro Antibacterial Properties of Garlic Extract against Some pathogenic bacteria isolated from burn unit
}

\author{
Iqbal Azeez Ameen * $\quad$ Hind Abdallah Salih * Ali Taher Abaas ** \\ * Biology department - Science College - Thi-Qar University \\ ** Branch of clinical sciences and Laboratory - College of Pharmacy - Thi-Qar University
}

\begin{abstract}
$\underline{\text { Abstract }}$
The antibacterial effects of aqueous garlic extract and Crude Juice against 38Gram-positive and Gram-negative bacterial isolates, from burn unit were studied. The bacteria isolates were including Staphylococcus spp. , Serratia spp. , Pseudomonas spp., Enterobacter spp., Acinetobacter. Spp. and Ochrobactrum anthropi. were studied. Antibacterial activity of aqueous garlic extract and Crude Juice by cup plate method was characterized by inhibition zones of diameter (14-34) $\mathrm{mm}$ for gram-positive bacteria and (14-32) $\mathrm{mm}$ for gram-negative bacteria respectively. The results of the study of garlic extract both types of aqueous extract and crude juice in the degree of impact inhibition as results showed that Crude Juice had a greater effect than aqueous extract effect.
\end{abstract}

Key words:-antibacterial effect, garlic and susceptibility

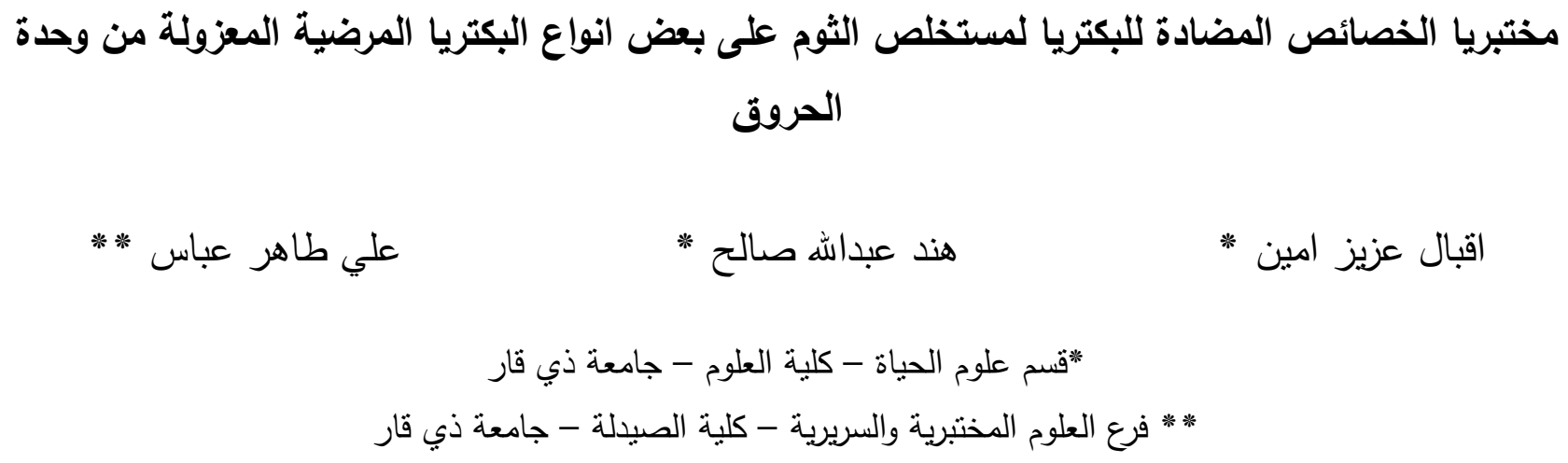

الخلاصة

التأثيرات ضد بكتيريا لمستخلص الثثم المائي والكحولي ضد رr عزلة بكتيرية سالبة وموجبة لصبغة كرام من وحدة الحروق تضمنت .

Staphylococcus spp. , Serratia spp. Pseudomonas spp., Enterobacter spp., Acinetobacter. Spp. and Ochrobactrum anthropi.

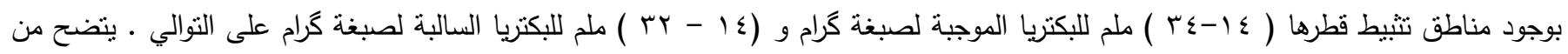

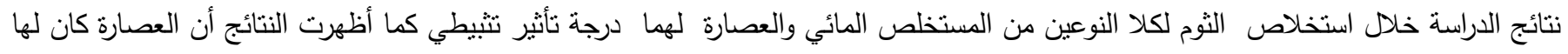
تأثثر أكبر من تأثير مستخلص المائي. الكلمات المفتاحية :. تأثنير المضاد البكتبري ، الثوم والحساسية الثية 


\section{Introduction}

Allium sativum, commonly known as garlic, is a plant belonging to the family of Lilliacease, which is native to central Asia and nowadays can be found throughout the world. Over the last centuries, various species of garlic have been used as spice or condiment for flavoring food. In herbal medicine, garlic has been prescribed for treating different kinds of diseases (Haciseferogullari et al., 2005 ). This plant is thought to be regulating the blood sugar and protecting the cardiovascular system. It also bears antibacterial, anticarcinogen, antioxidant and anti-inflammatory properties (Iwalokun et al., 2004). In addition, antibacterial effects of garlic on various types of bacteria have been reported in some studies (Sivam, 2001; Jazani, et al., 2007 ) . Immediately following wounding, whether it is caused by a severe burn, trauma or surgery, the affected area is at risk of colonization by a variety of micro-organisms, which proliferate within the damaged tissues and establish an infection (Rafla, and Tredget, 2011 ) . These microorganisms may come from the host's skin, respiratory or gastrointestinal flora (Posluszny, et al., 2011). Alternatively, they may reach the wound through contact with health care workers or come from environmental sources (Rafla, and Tredget, 2011 ; Posluszny, et al., 2011 ) . Microorganisms proliferating within the tissue may gain access to the bloodstream, the result of which can be sepsis, multiorgan failure and death (Church, et al., 2006 ). Such infections are responsible for $\sim 75 \%$ of mortality in burn patients (Rafla, and Tredget, 2011). The two most common bacteria causing burn wound infections are Staphylococcus aureus and Pseudomonas aeruginosa. (Rafla, and Tredget, 2011 ; Posluszny, et al., 2011 ) .

This broad spectrum of activity has been attributed to the over 100 hytotherapeutic sulfur compounds present in varying concentrations in garlic. They include allicin and thiosulfinates, which are formed by crushinginduced metabolic action of the enzyme allicinase (a cysteine sulfoxidelyase) on the odorless amino acid allicin (Lawson, et al., 1991 ) .

\section{Materials and methods}

Study design and setting: a cross sectional study had been conducted in burn unit in Al-Hussein hospital at Thi-qar ,one of the southern province in Iraq for the period from $1^{\text {st }}$ of November 2014 to the end of June 2015 .
1.Sampling : one hundred swabs were collected from the skin of patients in burn unit in Al-Hussein hospital at Thi-qar.

2. Cultural media : swabs were cultured on ; Blood agar, MacConkey agar and Nutrient agar, which were prepared according to the manufacture companies , and incubated at $37^{\circ} \mathrm{C}$ for $(24-48)$ hours.

3. Isolation and identification : Purification of bacterial growth colonies yield pure isolates of bacteria and subsequently their cultural , morphological , microscopically and biochemical characteristics had been studied according to (Retty, et al., 2007 ; Steven, et al., 2001, Finegold, ; Koneman, et al., 1992 and Martin, 1982 ) .

For identification of isolates the following kits were used:

API Staph kit (BioMeriux) for staphylococci identification

API 20E kit (BioMeriux) for Gram -ve bacilli identification

4. Antimicrobial Sensitivity tests : Susceptibility for the studied isolates were investigated according to ( Stocks, and Ridgway, 1987 ) by using Muller Hinton agar and the results were interpreted as recommended by( CLSI , 2009)and the following antibiotics discs were used : Ceftriaxone, Cefepime, Imipenem, Meropenem, Tetracyclines and Ciprofloxacin.

\section{5- Preparing and extraction of garlic 5-1 Aqueous extract}

According to Masoudi ( 2001 ), the preparation of the aqueous extract of garlic, garlic cloves removed and cut into small pieces A weight of $40 \mathrm{~g}$ garlic mix with water by (1: 2) (weight: volume) and mixed by electric mixer for 15 minutes and leave the solution for 30 minutes a piece of cloth used to separate large particulates, and centrifuged at $300 \mathrm{r} / \mathrm{min}$ for 10 minutes, then save in sterile bottles.

\section{5-2Crude Juice Preparation}

Mixing $10 \mathrm{~g}$ of chopped garlic cloves with $25 \mathrm{ml}$ of sterile distilled water and mixing in an electric mixer and used directly in the test ( Reuter, et al., 1996 ).

\section{6-Estimation of antibacterial activity of garlic extract}

Cup plate method

The antibacterial activity of the extracts was determined by using the agar well diffusion technique. Muller Hinton agar plates were needed with $0.1 \mathrm{ml}$ of overnight culture, allowed incubating for $24 \mathrm{hrs}$. cup were made in Petri plates using sterile cork borer $(0.85$ $\mathrm{cm})$ and $50 \mu \mathrm{l}$ of each extract was added into each well 
( Agarwal, 1976 ). Then bacterial plates were incubated at $37^{\circ} \mathrm{C} 24 \mathrm{hrs}$. Each test compound has got two bores for which zone of inhibition diameter and mean values were determined. Antibacterial activity was determined by measurement of zone of inhibition around each well in plate using zone reader.

\section{Results and Discussion}

Bacterial growth had been observed in 38 cultures (38\%) out of 100 swabs and samples which were collected from burn unit (Table 1).

The pure culture were divided into two groups depending on Gram stain, accordingly 17 Gram positive isolates and $21 \mathrm{GramNegative} \mathrm{isolates} \mathrm{were}$ identified. The most prevalent genus among Gram +ve bacteria was Staphylococcus spp. (11) isolates ( Table 1), The reason for this the rule of bacteria such as bacteria possess many surface antigens and enzymes that enable them to penetrate the body's tissues. This is one of the bacteria and pathogens that cause opportunistic infections because of the natural presence in or on the digestive and genital tract and nose and skin holding the bodies of her ( Landman, 2001). while the most prevalent genus among Gram -ve was Pseudomonas spp. ( 10 isolates ) had been found( Table 1).Susceptibility tests for some antibiotics showed different results depending on the genus of bacteria and type of antibiotics used For Pseudomonas spp. the resistance was highly significant against 4 antibiotics,(Cefepime, Ceftriaxone, Meropenem and Imipenem) The resistance was 100\%(Table 2) .while the resistance of Tetracycline and Ciprofloxacin antibiotics was 90\%(Table 2) which show consistency with a study that had been done in ( Nwobu, and Oguntibeju, 2004). In the ratio resistant bacteria Pseudomonas spp. to these antibiotics. The rest of all bacterial species have shown high resistance to antibiotics used(Table 2) .Such a high frequency and nature of antibiotic resistance may be due to over usage of antibiotics as well as no availability and high cost of preferred antibiotics of choice ( Edwards, and Greenwood, 2003). Increasingly bacteria are becoming multiple antibiotic resistant, leaving little or no effective systemic treatment option ( Neely, and Holder,1999). The bacteria Ochrobactrum anthropi did not show any resistance to antibiotics Ciprofloxacin, Imipenem and Meropenem. Where the inhibition zone of these bacteria $27 \mathrm{~mm}, 29 \mathrm{~mm}$ and 19 $\mathrm{mm}$ respectively (Table 2)The reason for inhibition is due to the scarcity of this type of bacteria.Seen from the results of the study during the garlic extract both types of Aqueous extract and Crude Juice showed that Crude Juice had a greater effect of aqueous extract effect (Table 3)..The Crude Juice his effect "inhibiting" for the growth of most bacterial species. This explains on the basis of what belongs the garlic of active substances, as it has several types of antibiotics most prominent the first and second Alistanin( Allistatin I \&II ) ( Chakravarty, 1979). The antimicrobial activity of garlic has been attributed to the presence of thiosulfinate materials (e.g: allicin) in which their complete removal render garlic to be ineffective against microorganisms (Hughes, and Lawson, 1991). Table 3 summarizes the result of the preliminary investigation of Aqueous extract and Crude Juice. The extract exhibited growth inhibition of both gram-positive and gram negative bacteria on Muller Hinton agar with inhibition zone diameter of 14-34 mm for gram-positive bacteria and 14-32 $\mathrm{mm}$ for gram-negative bacteria. which show inconsistency with a study that had been done in ( Iwalokun, et al., 2004 ) . Varied intensity of aqueous extract of garlic impact in the growth of the bacteria used in this study where we note in the [Table 3 ]. The minimum inhibitory concentration has reached $14 \mathrm{~mm}$ in two types Staph. Spp. and Pseudomonas. spp. and the highest inhibitor concentration was $30 \mathrm{~mm}$ in kind Staph . spp. The differences in the susceptibility of each test organism to the garlic extract may be directly related to the presence of secondary plant metabolites (thiosulfinates) and its concentration, in addition to the ability of microorganism to resist the antimicrobial agent that may occur because of multiple uses of antimicrobial agents in medicine ( Chen, and Chang, 1985).The aqueous extract given inhibition "for all isolates have been the reason is due to the ability of water to pull many of the active ingredients (alkaloids, saponins, sterols, and Turaaterpinoadat) from plant sources without other solvents, these compounds characterized by high impact on the inhibition of microbiology and particular bacteria ( Grimshow, 1976 ).[Table 3] shows the efficiency of the fresh juice on the inhibition of bacterial species studied where the minimum inhibitory concentration (16) $\mathrm{mm}$ in bacteria Pseudomonas spp. The highest inhibitory concentration $34 \mathrm{~mm}$ in bacteria. Allicin, the active ingredient of garlic, acts by partially inhibiting DNA and protein synthesis and also totally inhibiting RNA synthesis as a primary target ( Eja, et al., 2007 )The antimicrobial potency of plants is believed to be due to tannins, saponins, phenolic compounds, essential oils and flavonoids ( Griffiths, et 
al., 2002 ) . Organosulfur compounds and phenolic compounds have been reported to be involved in the garlic antimicrobial activity ( Jombo, et al., 2011 ; Aboaba, and Efuwape, 2001 ).

The garlic cutting and crushed in during the preparation of fresh juice increases the contact surfaces and then edit the active compounds ( Dankert, 1979 ). For this reason, we note that fresh juice gave effective against microbial more of the aqueous extract and antibiotics used.

Table 1- Bacterial isolates from burn unit and number of isolates and percentage

\begin{tabular}{|c|c|c|}
\hline Bacterial isolates & Numbers of Isolate & Percentage \\
\hline Staphylococcus spp. & 11 & 28.94 \\
\hline Serratia spp. & 6 & 15.78 \\
\hline Pseudomonas spp. & 10 & 26.31 \\
\hline Enterobacter spp. & 8 & 21.05 \\
\hline Acinetobacter spp. & 2 & 5.26 \\
\hline Ochrobacterum anthtopi & 1 & 2.63 \\
\hline TOTAL & 38 & $100 \%$ \\
\hline
\end{tabular}

Table 2 The effect of antibiotics on some pathogenic bacteria isolated from burn unit.

\begin{tabular}{|c|c|c|c|c|c|c|}
\hline \multirow[t]{2}{*}{ Antibiotics } & \multicolumn{6}{|c|}{ Types of bacteria } \\
\hline & $\begin{array}{l}\text { Pseudomonas } \\
\text { sp. }\end{array}$ & $\begin{array}{l}\text { Enterobacter } \\
\text { Spp. }\end{array}$ & Serratia spp. & $\begin{array}{l}\text { Acintobacter } \\
\text { Spp. }\end{array}$ & $\begin{array}{l}\text { Staphylococcus } \\
\text { spp. }\end{array}$ & $\begin{array}{l}\text { Ochrobactrum } \\
\text { anthropi }\end{array}$ \\
\hline $\begin{array}{l}\text { Ciprofloxacine } \\
\text { CIP }\end{array}$ & $\begin{array}{c}9 \\
90 \%\end{array}$ & $\begin{array}{c}5 \\
62.5 \%\end{array}$ & $\begin{array}{c}2 \\
33.3 \%\end{array}$ & $\begin{array}{c}2 \\
100 \%\end{array}$ & $\begin{array}{c}8 \\
72.7 \%\end{array}$ & $\mathrm{~S}(27)$ \\
\hline $\begin{array}{l}\text { Ceftriaxone } \\
\text { CTR }\end{array}$ & $\begin{array}{c}10 \\
100 \%\end{array}$ & $\begin{array}{c}8 \\
100 \%\end{array}$ & $\begin{array}{c}5 \\
83.3 \%\end{array}$ & $\begin{array}{c}2 \\
100 \%\end{array}$ & $\begin{array}{c}11 \\
100 \%\end{array}$ & $\begin{array}{l}1 \\
100 \%\end{array}$ \\
\hline $\begin{array}{l}\text { Cefepime } \\
\text { FEP }\end{array}$ & $\begin{array}{c}10 \\
100 \%\end{array}$ & $\begin{array}{c}8 \\
100 \%\end{array}$ & $\begin{array}{c}6 \\
100 \%\end{array}$ & $\begin{array}{c}2 \\
100 \%\end{array}$ & $\begin{array}{c}10 \\
90.9 \%\end{array}$ & $\begin{array}{l}1 \\
100 \%\end{array}$ \\
\hline $\begin{array}{l}\text { Imipenem } \\
\text { IMP }\end{array}$ & $\begin{array}{c}10 \\
100 \%\end{array}$ & $\begin{array}{c}6 \\
75 \%\end{array}$ & $\begin{array}{c}3 \\
50 \%\end{array}$ & $\begin{array}{c}2 \\
100 \%\end{array}$ & $\begin{array}{c}10 \\
90.9 \%\end{array}$ & $\mathrm{~S}(29)$ \\
\hline $\begin{array}{l}\text { Meropenem } \\
\text { MEM }\end{array}$ & $\begin{array}{c}10 \\
100 \%\end{array}$ & $\begin{array}{c}7 \\
87.5 \%\end{array}$ & $\begin{array}{c}3 \\
50 \%\end{array}$ & $\begin{array}{c}2 \\
100 \%\end{array}$ & $\begin{array}{c}10 \\
90.9 \%\end{array}$ & S(19) \\
\hline $\begin{array}{l}\text { Tetracyclines } \\
\text { TE }\end{array}$ & $\begin{array}{c}9 \\
90 \%\end{array}$ & $\begin{array}{c}8 \\
100 \%\end{array}$ & $\begin{array}{c}4 \\
66.6 \%\end{array}$ & $\begin{array}{c}2 \\
100 \%\end{array}$ & $\begin{array}{c}8 \\
72.7 \%\end{array}$ & $\begin{array}{c}1 \\
100 \%\end{array}$ \\
\hline
\end{tabular}

Table 3 Antibacterial activity of Garlic extracts against some pathogenic bacteria isolated from burin unit

\begin{tabular}{|c|c|c|c|c|c|c|}
\hline \multirow{2}{*}{ Extractions } & \multicolumn{7}{|c|}{ Types of bacteria } \\
\cline { 2 - 7 } & P. sp. & Entero. Sp. & S. sp. & Och. Sp. & Actino. Sp. & Staph. Sp. \\
\hline Aqueous & 14 & 15 & 16 & 24 & 16 & 14 \\
extract & 26 & 26 & 25 & & 20 & 30 \\
\hline \multirow{2}{*}{ Crude Juice } & 16 & 18 & 19 & 30 & 20 & 19 \\
& 30 & 30 & 32 & & 22 & 34 \\
\hline
\end{tabular}

\section{References}

Aboaba, O. and Efuwape, B. M. (2001) . Antibacterial properties of some Nigerian species. Bio Res Comm.13:183-188.

Agarwal, V.S. (1976) . Drug plants of India, Kalyani Publishers New Delhi, Vol 1, 52.

Chakravarty, H.L. (1979). Plant wealth of Iraqi adictionary economic plant. Ministry of Agriculture and Agration Reform, Baghdad-Iraq.

Chen, H.C. and Chang, T.J. (1985). Antibacterial properties of some spice plant before and after heat treatment. Pubmed, 18(3):190 - 195.

Church, D.; Elsayed, S.; Reid, O.; Winston, B. and Lindsay, R. (2006). Burn wound infections. ClinMicrobiol Rev 19, 403-434.

Clinical and Laboratory Standards Institute (CLSI) (2009). Performance standards for antimicrobial susceptibility testing. 19th Informational Supplement. CLSI Document M100-S19 Wayne, PA: CLSI.

Dankert, J.; Tromp, T.F.J.; De Vries, H.; and Klasen, H.J. ( 1979 ). Antimicrobial activity of crude juice of Allium ascatonicum , Allium cepa and Allium sativum. Zenterabl. Bacteriol. Parasitenkd. Infekrankh. Hyg. Abt. Lorg., 595: $229-239$.

Edwards, V. and Greenwood, J. (2003) What's new in burn microbiology? James Laing Memorial Prize Essay 2000. Burns 29(1): 15-24.

Eja, M. E.; Asikong, B. E; Abriba, C. ; Arikpo, G. E. ; Anwan, E.E. ; Enyi-Idoh, K. H. (2007 ) . A comparative assessment of the antimicrobial effects of garlic (Allium sativum) and antibiotics on diarrheagenic organisms. Southeast Asian J Trop Med Public Health.38:343-348.

Finegold, S.M. and Martin, W.J. ( 1982 ) : Diagnostic Microbiology, 6th ed. Mosby com.

Griffiths, G. ; Trueman, L. ; Crowther, T. ; Thomas, B. ; Smith, B. (2002 ). Onions - A global benefit to health. Phytother Res.16:603-615. 
Grimshow, J. ( 1976 ). Despside, hydrolysable tannins, lignans, lignin and humic acid Coffeye, Voll. 111, part D, Elsever Scientific Publishing Co., Amsterdam, Netherlands.

Haciseferogullari, H. ; Ozcan, M. ; Demir, F. and Calisir, S.( 2005) . Some nutritional and technological properties of garlic (Allium sativum L.). J Food Eng . 68(4): 463-9.

Hughes, B.G. and Lawson, L. (1991). Antimicrobial effects of allium sativum\& alliumcepa, garlic compound \& commercial garlic supplement product. phytother Res;5:154 - 158.

Iwalokun, B.A. ; Ogunledun, A. ; Ogbolu, D.O. ; Bamiro, S.B. and Jimi-Omojola, J.(2004). In Vitro Antimicrobial Properties of Aqueous Garlic Extract Against Multidrug-Resistant Bacteria and Candida Species from Nigeria. J Med Food 7 (3) : 327-333.

Jazani, N. H. ; Shahabi, S. ; Ali, A. ; Zarrin, S. and Daie, N. A. (2007) . In vitro antibacterial activity of garlic against isolates of Acinetobacter sp. J BiolSci. 7(5): 819-822.

Jombo, G.T.A. ; Emanghe, U. E. ; Amefule, U. E. ; Damen, J. G.( 2011 ) . Antimicrobial susceptibility profiles at a university hospital in Sub-Saharan Africa. Asian Pac J Trop Dis.2(1):7-11.

Koneman, E.W. ; Allen, S.D. ; Jawa, W.M. and Sachreckeber, P.C. (1992): Color Atlas and textbook of diagnostic microbiology, 4th ed. J.B. Lippincott com. Philadephia .

Landman, D. (2001). Mangement of infection due to resistance Staphylococcus aureus. Am. J. Infection. 30:225-240.

Lawson, L. D. ; Wood, S.G. and Hughes, B. G. ( 1991). HPLC analysis of allicin and other thiosulfinates in garlic clove homogenates. Planta Med. 57(3):263-70.

Masoudi, Hiam kalis. (2001). The use of garlic extracts and peels fruits of pomegranate in the treatment of infected mice whites Infected with trichomoniasis. Majstar- message Faculty of Sciences / University of Babylon.
Neely, A. N. and Holder, I. A. (1999) Antimicrobial resistance. Burns 25(1): 17-24.

Nwobu, R.A.U. and Oguntibeju, O.O. (2004). Occurrence of Pseudomonas aeruginosa in postoperative wound infection. Pak. J. Med. Sc., 20:187-191.

Posluszny, J. A.; Conrad, J. r. ; Halerz, P.; Shankar, M. R. and Gamelli, R. L. (2011). Surgical burn wound infections and their clinical implications. J Burn Care Res 32, 324-333.

Rafla, K. and Tredget, E. E. (2011). Infection control in the burn unit. Burns 37, 5-15.

Retty, A.F. ; Danil, F.S. and Aice S.W. ( 2007 ) : Balley and Scott's of Diagnostic Microbiology , 12th ed. Press, Houston, Texas .

Reuter, H.D.; Kock, H.P.; and Lawson, D.L. ( 1996 ). Therapeutic effects and applications in: garlic: The science and therapeutic applications of Allium sativumL. and related species. 2nd Ed. Pp. $135-212$.

Sivam, G. P.( 2001) . Protection against Helicobacter pylori and other bacterial infections by garlic. $\mathrm{J}$ Nutr. 131(3s): 1106S-1108S.

Steven, K.; Alexander, and Dennis, S. (2001) : Microbiology A photo- Graphic Atlas for Laboratory, 1st ed. Inc. San Francisco .

Stocks, E.J. and Ridgway, G. ( 1987 ) : Handaling clinical speciments for microbiology studies , 5th ed., Churchill Livingston, Edinburgh, $173-201$. 